Manuscript - submitted to the International Journal of Managing Projects in Business.

\title{
Dynamic capability through project portfolio management in service and manufacturing industries
}

Catherine P Killen, School of Systems, Management and Leadership, Faculty of Engineering and IT, University of Technology Sydney, Australia

Robert A Hunt, Macquarie Graduate School of Management, Macquarie University, Australia

Published as: Killen C P and Hunt R A (2010), “'Dynamic capability through project portfolio management in service and manufacturing industries", International Journal of Managing Projects in Business, Volume 3, Issue 1, pp 157-169.

The thesis reported can be accessed at: http://hdl.handle.net/1959.14/44777

\section{Abstract}

\section{Purpose}

This paper summarises a recent doctoral thesis on the relationship between project portfolio management (PPM) and competitive advantage in service and manufacturing organisations.

\section{Design/methodology/approach}

This two-phase mixed method study comprised a quantitative questionnaire-based survey and a qualitative multiple-case study to address the 'what' and the 'how' of the research questions.

\section{Findings}

This research adopted a 'dynamic capabilities' perspective, drawing on organisational learning theory to explain the path-dependent nature of PPM capability development and how PPM capabilities work with the resource base to enhance competitive advantage. Findings support prior PPM studies and suggest a positive relationship between structured PPM capabilities and improved outcomes. The research compared service and manufacturing environments; future challenges are likely to result from the increasing blurring of the boundaries between service and manufacturing industries. 


\section{Practical implications}

The research has four main practical outcomes: development of a model representing the overall PPM capability; a benchmark for and guidance on specific PPM processes and methods; guidance on the types of organisational learning investments that enhance the establishment and evolution of PPM capabilities; and the initial development of an outcomes and learning-based maturity model for PPM capabilities.

\section{Originality/value}

This research produced the first benchmark of innovation PPM capabilities in Australia, and is the first to include service product-focused portfolios. It is the first study that identifies PPM capabilities as dynamic capability, allowing existing research to be viewed through the dynamic capability lens and, more importantly, providing a theoretical underpinning that may influence future research and practice.

\section{Keywords}

Project portfolio management, dynamic capabilities, innovation, new product development, service development, organisational learning, doctoral thesis

\section{Summary of the doctoral thesis}

The research reported in this paper examined the relationship between innovation PPM capabilities and competitive advantage. Innovation projects - or projects for the development of new products - are of escalating importance in an increasingly competitive, globalised and deregulated environment characterised by shortening product lifecycles and dynamic markets (Lawson and Samson, 2001; Menor et al., 2002; Galende, 2006; Phaal et al., 2006; Kahn, 2007). Innovation PPM capabilities aim to improve the success rates for product innovation projects by providing a holistic and responsive decision-making environment to maximise the long-term value of innovation investments across the portfolio of innovation projects (Cooper et al., 2001; Levine, 2005).

Successful product innovation is no longer primarily a concern of manufacturingbased industries; product development in service industries is a growing endeavour in an increasingly important industry (Cooper and Edgett, 1999; Pilat, 2000; Edwards and Croker, 2001; Menor et al., 2002; Christensen and Drejer, 2007). Therefore this research included service product development environments and is the first to extend beyond the traditional manufacturing industry base for PPM research. In addition, although PPM is practised worldwide, PPM literature originates primarily in North America and Europe. There has been very little research related to PPM in Australia, and this is the first study to investigate innovation PPM capabilities in Australia.

A growing body of research aims at improving organisational competitive advantage through better understanding and improved success rates for innovation projects (Brown and Eisenhardt, 1995; Ernst, 2002). The literature indicates that managing a portfolio of innovation projects presents a multi-dimensional challenge that is often addressed through a PPM capability with a formal and structured process (Archer and 
Ghasemzadeh, 1999; Cooper et al., 2001; Cauchick Miguel, 2008). The literature on PPM outlines processes, methods and tools and identifies the 'best practices' associated with better outcomes (Loch, 2000; Cooper et al., 2001; Cormican and O'Sullivan, 2004; Jeffery and Leliveld, 2004; Norrie, 2006). An organisation's innovation PPM capability is responsible for ongoing decision-making to maintain the most effective combination of projects for new product and service development. The goals of the PPM capability are to align projects with the innovation strategy, maintain a balance of project types, and ensure that the project portfolio fits with resource capability so that the organisation can gain the maximum value from the investment in innovation projects (Cooper et al., 2002; Kendall and Rollins, 2003). In this way effective PPM processes are proposed to enhance an organisation's competitive advantage.

Organisations have always needed to make decisions about the best way to invest limited resources across a range of possible activities. However, the emergence of a distinct management capability or function for PPM is a fairly recent phenomenon (Cooper et al., 1997a, b; Levine, 2005). The past decade has seen an escalation in the amount of literature, research and practitioner activity focused on PPM, reflecting the increasing importance placed on PPM capabilities (Levine, 2005; Kwak and Anbari, 2009). The swell of interest in PPM can be attributed to two main trends, both essentially responses to the challenges presented by a globalised, information-rich, dynamic and competitive environment. First is the increasing perception that PPM capabilities maximise outcomes from innovation activities as organisations place more emphasis on innovation and organisational renewal (Cooper et al., 2001; Ernst, 2002). Second is the shift to 'management by projects' for organisational activities (Gareis, 1989: Turner, 1999), many of which were previously viewed as operational (Walker et al., 2008). Therefore projects are often the main vehicle for delivering organisational strategy (Turner, 1999; Poskela et al., 2003; Artto et al., 2004). This 'projectisation' of organisations has many drivers, including competitive pressures, increased complexity of organisational activities and the increasing availability and success of PM tools (Webb, 1994; Cleland, 1999). The growing interest in PPM has led to increasing levels of research in this area; however, there are many gaps in the literature.

\section{Overview of the Method}

The research investigated the relationship between an organisation's innovation PPM capability and its ability to establish sustained competitive advantage through improved new product outcomes. The research context was defined to address two of the major gaps in the literature: the lack of research on PPM in Australia and the lack of PPM research focusing on service industries. The research was therefore conducted in Australia and focussed on organisations that manage a portfolio of projects for the development of new products. These organisations represent both manufacturingbased and service-based product development environments. The research also aimed to better understand the establishment and evolution of PPM capabilities, and sought to apply or develop a theoretical framework to explain how PPM capabilities relate to competitive advantage.

A wide view of PPM capabilities was adopted including both PPM processes and organisational factors. The PPM processes investigated were the policies, practices, activities, procedures, methods and tools that managers use, while organisational 
factors included the organisational structures (level of influence, reporting structures, team structures, etc) and the human factors (levels of support and commitment for PPM, staffing considerations, effects on motivation, etc).

This research adopted a pragmatic perspective. It employed a sequential two-phase mixed-method study that comprised quantitative questionnaire-based survey and a qualitative multiple-case study to address the 'what' and the 'how' of the research questions. The use of the two methods enabled triangulation of the findings, enhancing reliability by limiting exposure to the particular limitations and biases of any single method (Brewer and Hunter, 1989; Creswell, 2003). Another benefit of the sequential approach is the ability to incorporate the results from one method in the research design for a subsequent method, and to enhance the ability of each phase of research to build upon the prior phase (Greene et al., 1989; Creswell, 2003).

Phase 1 employed a questionnaire-based survey designed to collect primarily quantitative data and test relationships between PPM practices and outcomes in both manufacturing and service organisations. The survey included multiple-item constructs to test relationships proposed in a conceptual model on PPM factors and outcomes. The survey also explored alternative ways of measuring the outcomes of PPM capabilities. Portions of the survey were similar to research conducted in North America (Cooper et al., 2001), allowing direct comparison between this study and the North American research. Based on responses from 60 Australian organisations (with a 36 percent survey return rate), the study provides the first comparable data for both service and manufacturing innovation PPM capabilities, as well as indications of relationships between practices and outcomes.

Phase 2 was designed using input from the findings of Phase 1 and an extended literature review. This qualitative phase comprised a multiple-case study focusing on six successful innovators in both manufacturing and service industries. The Phase 2 investigation allowed detail of the PPM environment to be explored and compared across the two types of industries. It added an additional perspective to address the research questions to support and extend the relationships identified in Phase 1. The dynamic capabilities framework was used to analyse the findings to improve the understanding of the relationship between PPM capabilities and competitive advantage. Phase 2 also provided new insight into the ongoing evolution and change in PPM capabilities in response to the environment in which they operate. This qualitative phase addressed the identified need for an integrated understanding of project and PPM practices and their multi-faceted environments (Winter et al., 2006).

\section{Context of the thesis}

The thesis summarised in this paper was submitted to the Macquarie Graduate School of Management (MGSM) in fulfilment of the requirements for the award of Doctor of Philosophy $(\mathrm{PhD})$. This research was conducted under the supervision of Associate Professor Robert A Hunt of the Centre for Management, Innovation and Technology (CMIT). MGSM is an autonomous unit of Macquarie University with campuses in the centre and suburbs of Sydney, Australia and in Hong Kong that focuses exclusively on graduate and executive management education and research.

The research was instigated by the author's earlier career focus on new technologies to enhance innovation processes, leading to an interest in how to best prioritise 
options, implement change and best improve innovation processes. The author's particular interest in PPM was developed through subsequent work on several research projects in the areas of technology management and strategy, and seminars and workshops conducted by A/Prof Robert (Bob) Hunt (MGSM) and Prof Elko Kleinschmidt (McMaster University). Due to the author's practice-based perspective, the research followed a strong practice orientation. The research linked theory with practice and contributed to the development of PPM practices - strongly supporting directions toward practice-based studies (Jarzabkowski and Wilson, 2006) and in line with identified research directions proposed in the 'rethinking' of project management research (Winter et al, 2006).

\section{Main findings}

The findings of the research have produced a benchmark of innovation PPM practices and outcomes in Australia. The research built on and supported prior research by highlighting the strategic importance of PPM capabilities and indicating positive relationships between aspects of PPM capabilities and new product outcomes (Killen et al., 2008a). The level of investment in learning and capability development was identified as a new factor in the relationship between PPM capabilities and outcomes. This research took a wide view of PPM capabilities and found that an organisation's PPM capability consists of supporting organisational structures and human dimensions in addition to the processes and methods used (Killen et al., 2008b). Figure 1 presents the model of PPM capabilities that was developed from the findings of the case studies, with PPM capabilities integrated with a set of stage-gate processes tailored to the environment and the project type. This model was proposed to help guide further research into PPM processes by highlighting the main elements that can be studied and how they interact. The model was also used to guide the development of a maturity model for PPM capability development. 




Figure 1: A model of an organisational PPM capability

\section{PPM in different contexts}

Both phases of the research found that the PPM capabilities in service and manufacturing environments are largely similar, with the main processes and dimensions of the capability common across environments. PPM capabilities were on 
average at a similar level of maturity, despite PPM being established more recently in the service industries. The areas of difference highlighted by both phases of research increase the understanding of the environments and how PPM capabilities are tailored to meet organisational and industry differences. PPM capabilities in service environments have special challenges that result from the dynamism in the market and technologies, short product lifecycles and the ability for products to be easily imitated or copied. PPM in manufacturing environments faces a different set of challenges with relatively inflexible resources in a dynamic competitive environment, and an ongoing trend toward an increasing service focus in their product offerings.

The in-depth findings in Phase 2 highlighted the challenges posed by the blurring of the boundaries between service and manufactured products (Killen, 2009). Manufacturing organisations need to adjust their strategy and develop better integration between project and business processes in order to most effectively manage the transition, as proposed by Gann and Salter (2000) and Auguste et al. (2006). This is an important and under-researched aspect of PPM capabilities and further research on service-related PPM is warranted, especially as many managers in the manufacturing environments reported that their organisations are steadily becoming service providers.

Responses to the Phase 1 survey showed a high level of similarity between PPM practices in Australia with North America. This finding reinforces the cultural clustering of Australia and North America with respect to PPM practices, and indicates that findings from the Australian PPM research may be relevant in North America and possibly also in other countries in the same Anglo-Celtic cluster (Harzing and Hofstede, 1996; Hofstede, 1997).

\section{PPM as a Dynamic Capability}

Previous PPM literature is primarily atheoretical and has been fragmented across a variety of perspectives and disciplines (Killen et al., 2007a). The research found that the resource-based view (RBV) and the dynamic capabilities framework are useful perspectives that can provide a unifying theoretical perspective for PPM research and help to explain the mechanisms through which PPM contributes to competitive advantage. The RBV has gathered support over the past two decades, and is now an influential, popular and fruitful area of strategy research (Verona, 1999; Hoopes et al., 2003). The RBV assumes that resources are not uniform across competing organisations and uses this heterogeneity to explain the differing organisational success rates. According to the RBV, resources that are valuable, rare, inimitable and non-substitutable (VRIN) form the best basis for sustainable competitive advantage by being difficult for other organisations to copy or acquire (Barney, 1991).

Despite its popularity, the RBV also attracts criticism because the path-dependent and evolutionary nature of the perspective is suited to relatively stable environments, requiring both internal organisational stability and external environmental stability to be applied in practice (Lengnick-Hall and Wolff, 1999). Therefore a major addition or extension to the RBV is the identification of 'dynamic capabilities' as a class of organisational capabilities that enable organisations to effectively respond to changes in the dynamic environments in which they compete (Teece et al., 1997). The dynamic capabilities approach focuses on the processes used in organisations to integrate, build and reconfigure their resources to compete in dynamic environments. 
The RBV and dynamic capabilities framework are increasingly being used to understand the relationship between organisational capabilities and competitive advantage. Through the RBV, project management capabilities have been shown to be a strategic asset through a combination of tangible and intangible aspects (Jugdev, 2004, 2007; Jugdev et al., 2007). The RBV and the dynamic capabilities framework have also been used to understand learning and capability building processes in project management environments (Davies and Brady, 2000; Brady and Davies, 2004; Söderlund et al., 2008). In addition, the dynamic capabilities framework has been applied to studies on organisational learning capabilities, strategic alliancing capabilities and new venture creation strategies (Helfat, 2000; Zollo and Winter, 2002; Antonacopoulou et al., 2005; Prieto and Easterby-Smith, 2006).

As the dynamic capabilities framework is relatively new, more empirical research is required to strengthen and develop the field (Eisenhardt and Martin, 2000; Zahra et al., 2006; Martinsuo and Lehtonen, 2007). The dynamic capabilities framework has not previously been applied to the study of PPM capabilities, yet resource allocation processes are a central aspect of PPM capabilities, and there is support in the literature for treating resource allocation processes as dynamic capabilities (Eisenhardt and Martin, 2000). Processes for resource allocation are said to be "clearly relevant to dynamic capabilities because they directly deal with changes to the resource position of an organisation" (Helfat et al., 2007:32).

The case study findings strongly support the use of the dynamic capabilities perspective to explain and understand how PPM capabilities contribute to competitive advantage. The research used the 'processes, positions and paths' (PPP) dynamic capability framework of Teece et al. (1997) to structure existing PPM research and illuminate the relationships between the processes used for PPM, the resource position of the organisation, and the historical paths and future options available (Killen et al., 2007b). This framework was then used to analyse the in-depth case study findings. Figure 2 illustrates the relationships between the PPM processes, the resource position, past and future paths, and the development of competitive advantage in a dynamic environment. The model also includes the three PPM capability elements of processes, structures and people as identified in Figure 1. 


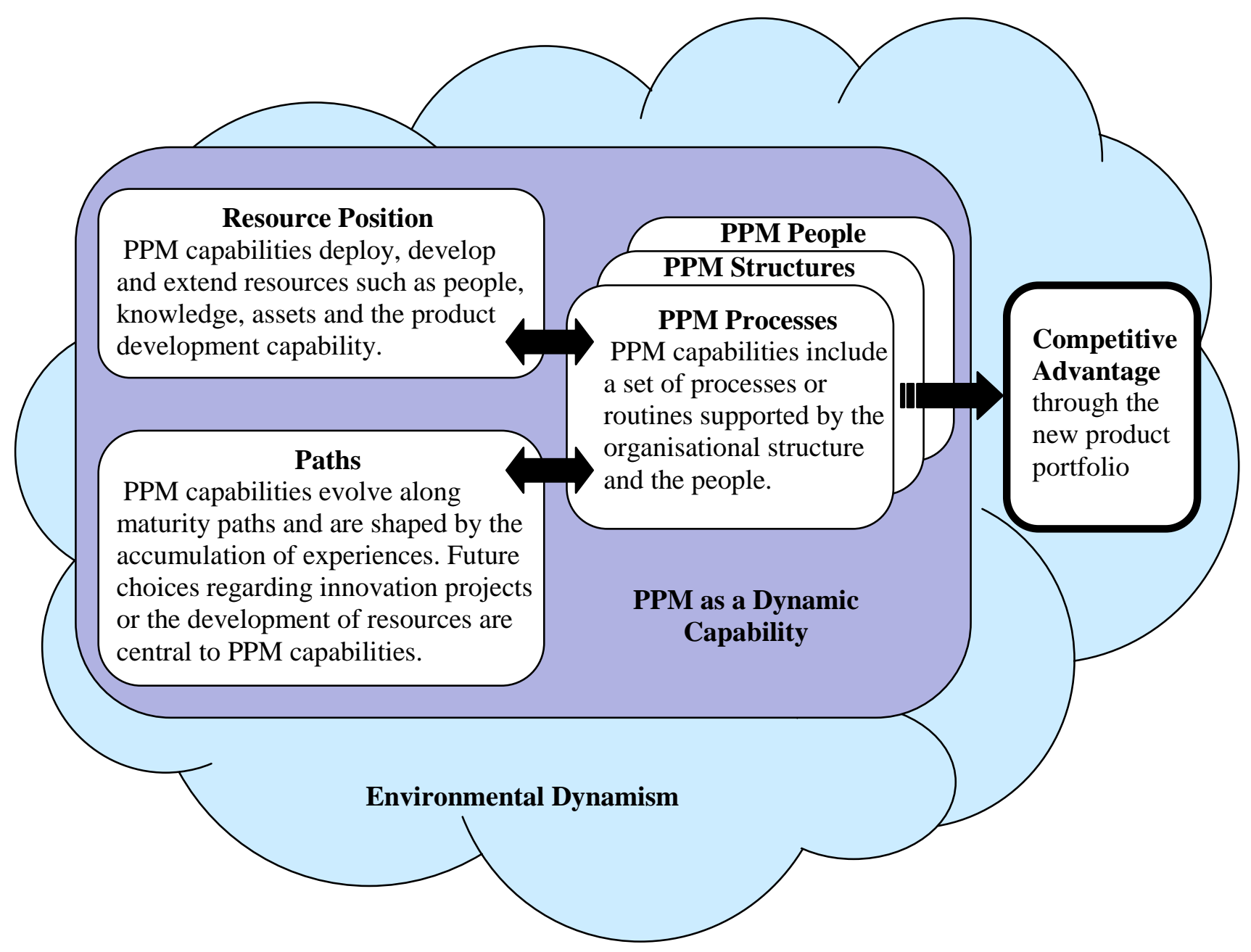

Figure 2: PPM as a dynamic capability illustrating the processes, positions and paths framework

\section{Learning and capability evolution}

The case study findings show that organisational learning has a large role to play in the establishment and continual evolution of PPM capabilities in response to the dynamic competitive environment. The findings support the proposition that dynamic capabilities co-evolve through a combination of tacit and explicit learning mechanisms, and that investments in organisational learning activities are regularly used to enhance these learning mechanisms (Zollo and Winter, 2002; Killen et al., 2008c). The findings also indicate relationships between establishment and evolution of PPM and type of learning investments (Killen et al., 2008c).

The PPM capability provides a locus for the decision-making processes that enhances ability of experiences to accumulate and the learning to be captured. However, once a PPM capability is established and decision-making experiences accumulate, the 
findings from the case-study organisations show evidence of unintentional capability evolution. Each of the case organisations reported that their PPM process has shown symptoms of the 'success trap' (also referred to as the 'exploitation trap') by tending to favour short-term, incremental or low-risk 'exploitation' projects at the expense of the more radical, breakthrough longer-term 'exploration' projects that they believe are essential for long-term success (March, 1991; Levinthal and March, 1993; Danneels, 2002; Benner and Tushman, 2003). While the PPM capabilities at the case organisations were found to have a strong role in creating this 'success trap', they are also the main avenue for identifying and addressing it. Research participants at each of the case organisations reported that they had adjusted, or were planning to adjust, their PPM capability to redress the imbalance.

The findings on PPM capability evolution were also used to develop an initial version of an 'outcomes and learning-based maturity model' for PPM. The maturity model is designed to help organisations analyse their PPM capability, tailor the PPM processes to suit their environment, avoid some of the pitfalls such as the 'success trap', and identify areas for improvement (Killen and Hunt, 2009).

\section{Limitations and Future Research}

The findings are based on Australian organisations representing a diverse range of industries. The 60 organisations represented in the quantitative Phase 1 survey and the six organisations studied in the qualitative Phase 2 multiple-case study may not be representative of all organisations or all environments. This research has provided initial insights into PPM capabilities in service development environments. Further research is required to extend the investigation into service PPM and to determine whether these initial findings are representative of other service environments. Future research is recommended to test the models proposed in this thesis, such as those presented in figures 1 and 2, and others such as the maturity model which are not presented here. Finally, the data for this study were collected over a short period of time at each organisation and focussed on the past evolution and future plans for the PPM capability. Future research employing longitudinal studies would enhance the understanding of learning processes and the evolution of PPM capabilities over time.

\section{Conclusion}

This research makes two major contributions. The first is the increased understanding of PPM in service organisations. The findings address a major gap in the literature, given the significant and escalating importance of services to the economy of developed nations. Although PPM has been established more recently in service industries, the findings reveal that the capabilities have developed relatively quickly and are at a similar level of maturity to the PPM capabilities in manufacturing industries. PPM processes are found to be similar overall, with unique challenges and drivers for the PPM capabilities in each industry. The research also provides a valuable perspective on the service PPM environment and on the changing nature of products. The findings illustrate the blurring of the boundaries between service and manufactured products, highlighting the importance of understanding both similarities and differences in PPM capabilities between the two environments in order to best tailor PPM capabilities for hybrid environments. 
The second major contribution of this research is the identification of a PPM capability as a 'dynamic capability' and the use of the dynamic capabilities perspective and the RBV to improve understanding of how PPM capabilities contribute to sustained organisational competitive advantage. Prior PPM research has been primarily atheoretical and has originated from multiple perspectives and disciplines. The dynamic capabilities framework provides a perspective to explain the mechanisms through which PPM capabilities draw upon and develop the resource base and contribute to competitive advantage. This research contributes empirical findings to illustrate and examine dynamic capabilities in action, thus strengthening the understanding of dynamic capabilities. In addition, organisational learning capabilities are found to underpin the dynamic capability and enable PPM capabilities to develop and evolve in response to the environment. In this way PPM capabilities can remain dynamic and sustainably contribute to competitive advantage.

\section{References}

Antonacopoulou, E., Ferdinand, J., Graca, M. and Easterby-Smith, M. (2005), "Dynamic capabilities and organizational learning: Socio-political tensions in organizational renewal", Advanced Institute of Management Research AIM Working Paper Series: 014, January 2005.

Archer, N.P. and Ghasemzadeh, F. (1999), "An integrated framework for project portfolio selection", International Journal of Project Management, Vol. 17 No. 4, pp. 207-216.

Artto, K.A., Dietrich, P.H. and Nurminen, M.I. (2004), "Strategy implementation by projects", in Slevin, D.P., Cleland, D.I. and Pinto, J.K. (Eds.), Innovations: Project management research 2004, Project Management Institute, Newtown Square, PA, pp. 103-122.

Auguste, B.G., Harmon, E.P. and Pandit, V. (2006), "The right service strategies for product companies", McKinsey Quarterly, Vol. 1, pp. 40-51.

Barney, J. (1991), "Firm resources and sustained competitive advantage", Journal of Management, Vol. 17 No. 1, pp. 99-120.

Benner, M.J. and Tushman, M.L. (2003), "Exploitation, exploration, and process management: The productivity dilemma revisited", Academy of Management Review, Vol. 28 No. 2, pp. 238-256.

Brady, T. and Davies, A. (2004), "Building project capabilities: From exploratory to exploitative learning", Organization Studies, Vol. 25 No. 9, pp. 1601-1621.

Brewer, J. and Hunter, A. (1989), Multimethod Research: A Synthesis of Styles, SAGE Publications, Thousand Oaks, CA.

Brown, S.L. and Eisenhardt, K.M. (1995), "Product development: Past research, present findings, and future directions", Academy of Management Review, Vol. 20 No. 2, pp. 343-378. 
Cauchick Miguel, P.A. (2008), "Portfolio management and new product development implementation: A case study in a manufacturing firm", International Journal of Quality \& Reliability Management, Vol. 25 No. 1, pp. 10-23.

Christensen, J.L. and Drejer, I. (2007), Blurring Boundaries Between Manufacturing and Services, ServINNo report, Service Innovation in the Nordic Countries: Key Factors for Policy Design.

Cleland, D.I. (1999), "The strategic context of projects", in Dye, L.D. and Pennypacker, J.S. (Eds.), Project Portfolio Management: Selecting and Prioritizing Projects for Competitive Advantage, Center for Business Practices, Havertown, PA.

Cooper, R.G. and Edgett, S.J. (1999), Product Development for the Service Sector, Perseus Books, Cambridge, MA.

Cooper, R.G., Edgett, S.J. and Kleinschmidt, E.J. (1997a), "Portfolio management in new product development: Lessons from the leaders - I", Research Technology Management, Vol. 40 No. 5, pp. 16-28.

Cooper, R.G., Edgett, S.J. and Kleinschmidt, E.J. (1997b), "Portfolio management in new product development: Lessons from the leaders - II", Research Technology Management, Vol. 40 No. 6, pp. 43-52.

Cooper, R.G., Edgett, S.J. and Kleinschmidt, E.J. (2001), Portfolio Management for New Products, 2nd ed, Perseus, Cambridge, MA.

Cooper, R.G., Edgett, S.J. and Kleinschmidt, E.J. (2002), “Optimizing the stage-gate process: What best-practice companies do - II", Research Technology Management, Vol. 45 No. 6, pp. 43-49.

Cormican, K. and O'Sullivan, D. (2004), “Auditing best practice for effective product innovation management", Technovation, Vol. 24 No. 10, pp. 819-829.

Creswell, J.W. (2003), Research Design: Qualitative, Quantitative, and Mixed Method Approaches, 2nd ed, SAGE Publications, Thousand Oaks, CA.

Danneels, E. (2002), "The dynamics of product innovation and firm competences", Strategic Management Journal, Vol. 23 No. 12, pp. 1095-1121.

Davies, A. and Brady, T. (2000), “Organisational capabilities and learning in complex product systems: Towards repeatable solutions", Research Policy, Vol. 29 No. 7-8, pp. 931-953.

Edwards, M. and Croker, M. (2001), "Major trends and issues, innovation and productivity in services", Industry, Services \& Trade, OECD Publications Service, Vol. 33, pp. 7-16.

Eisenhardt, K.M. and Martin, J.A. (2000), "Dynamic capabilities: What are they?" Strategic Management Journal, Vol. 21 No. 10/11, pp. 1105-1121. 
Ernst, H. (2002), "Success factors of new product development: A review of the empirical literature", International Journal of Management Reviews, Vol. 4 No. 1, pp. 1-40.

Galende, J. (2006), “Analysis of technological innovation from business economics and management", Technovation, Vol. 26 No. 3, pp. 300-311.

Gann, D.M. and Salter, A.J. (2000), "Innovation in project-based, service-enhanced firms: The construction of complex products and systems", Research Policy, Vol. 29, pp. 955-972.

Gareis, R. (1989). “'Management by projects': the management approach for the future." International Journal of Project Management. 7 (4): 243-249.

Greene, J.C., Caracelli, V.J. and Graham, W.F. (1989), "Toward a conceptual framework for mixed-method evaluation design", Educational Evaluation and Policy Analysis, Vol. 11 No. 3, pp. 255-274.

Harzing, A.-W. and Hofstede, G. (1996), "Planned change in organizations: The influence of national culture", Research in the Sociology of Organizations, Vol. 14, pp. 297-340.

Helfat, C.E. (2000), "Guest editor's introduction to the special issue: The evolution of firm capabilities”, Strategic Management Journal, Vol. 21 No. 10/11, pp. 955959.

Helfat, C.E., Finkelstein, S., Mitchell, W., Peteraf, M.A., Singh, H., Teece, D.J. and Winter, S.G. (2007), Dynamic Capabilities: Understanding Strategic Change in Organizations, Blackwell, Malden, MA.

Hofstede, G. (1997), Culture and Organizations: Software of the Mind, 2nd ed., McGraw-Hill, New York.

Hoopes, D.G., Madsen, T.L. and Walker, G. (2003), "Guest editors' introduction to the special issue: Why is there a resource-based view? Toward a theory of competitive heterogeneity", Strategic Management Journal, Vol. 24 No. 10, pp. 889-902.

Jarzabkowski, P and Wilson, D C (2006), “Actionable strategy knowledge: A practice perspective”, European Management Journal, Vol. 24 No. 5, pp. 348-267.

Jeffery, M. and Leliveld, I. (2004), "Best practices in it portfolio management", MIT Sloan Management Review, Vol. 45 No. 3, pp. 41-49.

Jugdev, K. (2004), "Through the looking glass: Examining theory development in project management with the resource-based view lens", Project Management Journal, Vol. 35 No.3, pp. 15-26.

Jugdev, K. (2007), "Closing the circle: The knowledge management spiral of project management", International Journal of Knowledge Management Studies, Vol. 1 No. 3/4, pp. 423-441. 
Jugdev, K., Mathur, G. and Fung, T. (2007), "Project management assets and their relationship with the project management capability of the firm", International Journal of Project Management, Vol. 25 No. 6, pp. 560-568.

Kahn, E. (2007), Innovate or Perish, John Wiley and Sons, Inc, Hoboken.

Kendall, G.I. and Rollins, S.C. (2003), Advanced Project Portfolio Management and the PMO: Multiplying ROI at Warp Speed, J. Ross Publishing, Boca Raton, FL.

Killen, C.P. (2009), "Trends in product innovation: How manufacturing and services blend", Proceedings of ANZAM 2009, Melbourne, Australia, Australia and New Zealand Academy of Management, 2-4 December.

Killen, C.P. and Hunt, R.A. (2009), "Project portfolio management maturity model for dynamic environments", Proceedings of the AIPM (Australasian Institute of Project Management) conference, October 11-14, Adelaide.

Killen, C.P., Hunt, R.A. and Kleinschmidt, E.J. (2007a), "Managing the New Product Development Project Portfolio: A Review of the Literature and Empirical Evidence", in Proceedings of PICMET 2007, Portland, Oregon, Portland International Conference on Managing Engineering and Technology (PICMET), 5-9 August.

Killen, C.P., Hunt, R.A. and Kleinschmidt, E.J. (2007b), "Dynamic Capabilities: Innovation Project Portfolio Management", Proceedings of ANZAM 2007, Sydney, Australia, Australia and New Zealand Academy of Management, 4-7 December.

Killen, C.P., Hunt, R.A. and Kleinschmidt, E.J. (2008a), "Project portfolio management for product innovation", International Journal of Quality and Reliability Management, Vol. 25 No. 1, pp. 24-38.

Killen, C.P., Hunt, R.A. and Kleinschmidt, E.J. (2008b), "The human factor in innovation project portfolio management", in Inside the Innovation Matrix: Finding the Hidden Human Dimensions. Australian Business Foundation, North Sydney, pp. 158-176.

Killen, C.P., Hunt, R.A. and Kleinschmidt, E.J. (2008c), "Learning investments and organisational capabilities: Case studies on the development of project portfolio management capabilities", International Journal of Managing Projects in Business, Vol. 1 No. 3, pp. 334-351.

Kwak, Y.H. and Anbari, F.T. (2009), "Analyzing project management research: Perspectives from top management journals", International Journal of Project Management, Vol 27 No 5, pp. 435-446.

Lawson, B. and Samson, D. (2001), "Developing innovation capability in organisations: A dynamic capabilities approach", International Journal of Innovation Management, Vol. 5 No. 3, p. 377. 
Lengnick-Hall, C.A. and Wolff, J.A. (1999), "Similarities and contradictions in the core logic of three strategy research streams", Strategic Management Journal, Vol. 20 No. 12, pp. 1109-1132.

Levine, H.A. (2005), Project Portfolio Management: A Practical Guide to Selecting Projects, Managing Portfolios, and Maximizing Benefits, Chichester, JosseyBass; John Wiley distributor, San Francisco, CA.

Levinthal, D.A. and March, J.G. (1993), "The myopia of learning", Strategic Management Journal (1986-1998), Vol. 14 (Special issue), pp. 95-112.

Loch, C. (2000), "Tailoring product development to strategy: Case of a European technology manufacturer", European Management Journal, Vol. 18 No. 3, pp. 246-258.

March, J.G. (1991), "Exploration and exploitation in organizational learning", Organization Science, Vol. 2 No. 1, pp. 71-87.

Martinsuo, M. and Lehtonen, P. (2007), "Role of single-project management in achieving portfolio management efficiency", International Journal of Project Management, Vol. 25 No. 1, pp. 56-65.

Menor, L.J., Tatikonda, M.V. and Sampson, S.E. (2002), "New service development: Areas for exploitation and exploration", Journal of Operations Management, Vol. 20 No. 2, pp. 135-157.

Norrie, J. L. (2006), "Improving Results of Project Portfolio Management in the Public Sector Using a Balanced Scorecard Approach", Doctor of Project Management, School of Property, Construction and Project Management. Melbourne, RMIT University.

Phaal, R., Farrukh, C.J.P. and Probert, D.R. (2006), “Technology management tools: Concept, development and application", Technovation, Vol. 26 No. 3, pp. 336344.

Pilat, D. (2000), "No longer services as usual", OECD Observer, Vol. 223 (November).

Poskela, J., Dietrich, P. and Artto, K.A. (2003), "Organizing for managing multiple projects - a strategic perspective", paper presented at the 17th Conference on Business Studies in Reykjavik, 14-16 August.

Prieto, I.M. and Easterby-Smith, M. (2006), "Dynamic capabilities and the role of organizational knowledge: An exploration", European Journal of Information Systems, Vol. 15 No. 5, pp. 500-510.

Söderlund, J., Vaagaasar, A.L. and Andersen, E.S. (2008), "Relating, reflecting and routinizing: Developing project competence in cooperation with others", International Journal of Project Management, Vol. 26 No. 5, pp. 517-526. 
Teece, D.J., Pisano, G. and Shuen, A. (1997), "Dynamic capabilities and strategic management", Strategic Management Journal (1986-1998), Vol. 18 No. 7, pp. 509-533.

Turner, J.R. (1999), The Handbook of Project-Based Management: Improving the Process for Achieving Strategic Objectives, 2nd ed., McGraw-Hill, London.

Verona, G. (1999), "A resource-based view of product development", Academy of Management Review, Vol. 24 No.1, pp. 132-142.

Walker, D.H.T., Arlt, M. and Norrie, J. (2008), "The role of business strategy in pm procurement", in Walker, D.H.T. and Rowlinson, S. (Eds.), Procurement Systems - a Cross Industry Project Management Perspective, Taylor \& Francis, Abingdon, pp. 140-176.

Webb, A. (1994), Managing innovative projects, Chapman \& Hall, London, New York.

Winter, M., Smith, C., Morris, P. W. G. and Cicmil, S. (2006), "Directions for future research in project management: The main findings of a UK governmentfunded research network." International Journal of Project Management. Vol. 24 No. 8, pp. 638-649.

Zahra, S.A., Sapienza, H.J. and Davidsson, P. (2006), "Entrepreneurship and dynamic capabilities: A review, model and research agenda", Journal of Management Studies, Vol. 43 No. 4, pp. 917-955.

Zollo, M. and Winter, S.G. (2002), "Deliberate learning and the evolution of dynamic capabilities”, Organization Science, Vol. 13 No. 3, pp. 339-351. 